\title{
The United States
}

\author{
FRANCISCO E. GONZÁLEZ and \\ DESMOND KING
}

Any discussion of the United States' political democratization is fundamentally complicated by its role since 1917 as a global model and defender of liberal democracy, a role that burgeoned after 1941. As a consequence of this responsibility, historically the United States' democratization has been both a domestic and international process. National and international politics have presented two trajectories that cohere into a common narrative of democratization (King 2004). This narrative is a continuing one.

Domestically, the hundred years after the Civil War (1861-65) were characterized by a gradual abandonment of narrow assimilationism and the enactment - in the 1960s of legislation, prompted by the civil rights movement (Morris 1984), to uphold the rights of citizenship of all Americans. Addressing the legacies of pre-1960s discrimination and racism (Fields 1990; Jordan 1968; Kelley 1994) proved a platform for a multiculturalist reformulation of American national identity, or in David Hollinger's phrase a 'post-ethnic politics' (Hollinger 1995). The transformation of US politics from a narrowly based assimilationist and exclusionary system to a broadly defined and inclusive democracy is the major story of its twentieth-century politics. The historian Gary Gerstle characterizes this shift as a turn from 'racial' nationalism to 'civic' nationalism (Gerstle 2001).

There was a parallel international story. In 1917, President Woodrow Wilson decided to bring the United States into the European theatre of the First World War as an opportunity to 'make the world safe for democracy', and outlined his (unrealized) Fourteen Points for a post-war liberal order. In 1941, President Franklin D. Roosevelt responded to the 
Pearl Harbor attack by both leading the United States into the Second World War and formulating (jointly with allies) the Atlantic Charter doctrine for the post-1945 world. This Charter was quintessentially American in its aspirations. Its renunciation of imperialism (a stance opposed by Great Britain) aligned the United States with a future world order of liberal democratic states. The Truman Doctrine, as effected in the defence of democracy in Greece in 1947, confirmed these values, while the other Western powers' post-war infirmity made the United States the key Western defender against communism. President Ronald Reagan articulated the keystone of his administration's foreign policy as the defeat of the 'evil empire', Soviet communism. These external postures were accompanied by foreign scrutiny and criticism of the United States' own democratic practices toward minorities and people of colour. Maintaining the United States' integrity abroad necessitated remedying its own democratic deficit; this duality illustrates the overlapping effects of domestic and international politics in the formation of American nationhood.

In the next section the conventional timing of the United States' democratization is assessed, a prelude to considering how best to conceive the core beliefs and values of American nationhood. The discussion then examines how international pressures influenced the democratization enacted in the 1960s. The present role of the United States as a domestic and international emblem of liberal democracy concludes the chapter.

\section{First new nation or late democratizer?}

Although commonly cited as the world's first liberal democracy (Lipset 1963, 1996; McElroy 1999), in many ways the United States was also a remarkably late democratizer. Not until the passage of the Civil Rights Act in 1964 and the Voting Rights Act in 1965 (and the related US Supreme Court judgment in 1971) did the United States fully guarantee the basic democratic right to vote to all its citizens and protection of civil rights, that is, the conditions for Robert Dahl's idea of polyarchy. In practice, until the mid-1960s 
the United States presented the picture of a restricted democracy with significant parts of its citizenry de facto or de jure excluded from democratic participation. This pattern subverted the triumph of the North in the Civil War. Reconstruction led to segregation, and this consolidated an exclusionary democracy in the United States, which persisted for one hundred years after the North-South conflict. The core values of American nationhood expressed in the Declaration of Independence and the Constitution were thus thwarted, and could not be a reality until the federal government was able to enforce the nationwide protection of civil rights and the guarantee of free and fair contestation and participation in genuine democratic elections. This did not happen until the late 1960s.

This picture is at variance with the conventional narrative presented in those accounts of America's political development reliant upon Alexis de Tocqueville's nineteenthcentury survey and Louis Hartz's articulation of American 'individualist' liberalism (Hartz 1955). Foremost amongst this new, reflective, American scholarship is the work of the political scientist Rogers Smith, who wrote: 'for over 80 per cent of US history, its laws declared most of the world's population to be ineligible for full American citizenship solely because of their race, original nationality or gender. For at least two-thirds of American history, the majority of the domestic adult population was also ineligible for full citizenship for the same reasons. Contrary to Tocquevillian views of American civic identity, it did not matter how "liberal", "democratic", or "republican" those persons' beliefs were. The Tocquevillian story is thus deceptive because it is too narrow. It is centred on relationships among a minority of Americans (white men, largely of northern European ancestry)' (Smith 1993: 549). Rogers Smith's broadening of the historical narrative of American democracy offers one in which attention is given to the United States' 'multiple traditions' (Smith 1997). This multiple traditions thesis finds in US politics and history numerous examples of political elites attempting to define American identity as one rooted in inegalitarian ascriptive themes. It provides the ideational context in which coexisting political ideologies competed to win dominance (Stears 2001). 
Another characteristic of standard accounts of the United States' political development to liberal democracy is their teleological form (Gerstle 2001). In this view, the United States shifted from a condition of imperfect individualism, the imperfections commonly reflecting discrimination against individuals because of their association with certain groups, to one of formal equality of individual rights, and in some accounts to multiculturalism. This influential version of the transformative narrative underestimates the endurance of group-based distinctions in American national identity. It neglects the continuing salience of issues once considered settled (as for instance in the movement for reparations for slavery) and overlooks how the United States' international presence, as a defender and model of democracy, exposes its domestic policy to foreign scrutiny.

Historians and social scientists have emphasized the 'exceptional' character of American democratization, a term with several implications. First, the weakness of class-based divisions - as expressed in political behaviour - compared with the effects of such divisions as race, region and religion distinguish the United States comparatively (Sombart 1976; Goldfield 1997; Nelson 2000). Second, the effects of federalism, which not only produced parallel party systems, rooted in local communities and then organized at state and federal level, but encouraged voters to maintain strong ethnic or regional loyalties. Ira Katznelson argues that a distinction between the politics of community and the politics of work is a feature of American politics, with significant effects (Katznelson 1981). A third factor, suggested by the 'third wave' democratization literature, is the distinctive character of the US state (González and King, forthcoming). The federal government or 'state' demonstrated a historical bias, between the 1880s and 1960s, in favour of segregationist policies, and instead of challenging the legality of 'separate but equal' arrangements (the system upheld by the US Supreme Court between 1896 and 1954) often fostered their diffusion (King 1999). As a set of bureaucratic resources and institutions, the US federal state also appeared weakly placed to advance democratization in comparison with other liberal democracies (González and King, forthcoming).

These sources of 'exceptionalism' identify distinct factors in the United States' national identity as a democracy, 
but do not obviate the need to acknowledge the lateness - comparatively speaking - of the establishment of full democracy.

\section{Nationhood, individualism and groups}

One important implication of a broader, multiple traditions, account of the United States' democratization path is the need to re-consider the content of American national identity. This latter combines a rich individualism, guaranteed in constitutional rights, with a reality of wide group loyalties and ties, based variously upon ethnicity, national background or race. Politically, a tension has endured between the individualist and the group components of Americanism: in practice, American nationalism has consisted in both individualism and group identities. This is not quite the 'post ethnic' identity envisaged by David Hollinger (1995); but it is a richer conception than that expressed in traditional accounts. The change is epitomized by the comments of Woodrow Wilson in 1917 compared with those of President George W. Bush in 2001. Wilson declaimed, 'you can not become thorough Americans if you think of yourselves in groups. America does not consist of groups. A man who thinks of himself as belonging to a particular national group in America has not yet become an American.' He condemned 'hyphenated Americans' as un-American. In contrast, within days of the 11 September 2001 bombings George Bush purposefully visited a mosque in Washington and, speaking in Congress, expressed support to Arab and Muslim Americans.

Wilson's comments epitomize the contemporary expectation of assimilation promoted federally between the 1870s and the 1960s. The political imperative to construct an assimilationist conception of American national identity, before the 1960s, arose from the United States' engagement with Native Americans, openness to immigrants and acceptance of segregation. Historically, Americans worried about threats to national identity arising from unsuitable immigrants. Between 1882 and 1965 the United States operated a restrictionist immigration policy based in discriminatory guidelines (King 2000). Since 1965, the United States has 
established a non-discriminatory, liberal immigration regime that has included periodic amnesties for illegal immigrants.

\section{The international context}

Since 1917, but particularly from 1941, the United States has acted as the pre-eminent defender of liberal democracy in two senses. First, it has espoused democratic values in its political institutions and political culture and offered them, at times explicitly, as suitable for emulation by other states. Second, it has served as the principal military enforcer of democracy against totalitarianism, in its various guises.

The Truman presidency (1945-52) rejected US isolationism, both for pragmatic reasons (the Soviet Union and China would exploit such a withdrawal through expansionism) and for ideological motives, the 'imponderable, but nevertheless drastic effects on our beliefs in ourselves and in our way of life of a deliberate decision to isolate ourselves' (in Etzold and Gaddis 1978: 432). President Truman's National Security Council (NSC) articulated the worth of defending the United States because of its profound commitment to individual liberty and a free society: 'the idea of freedom is the most contagious idea in history, more contagious than the idea of submission to authority' (in Etzold and Gaddis 1978: 388). Anti-communism and anti-totalitarianism drove US foreign policy from 1947 and dictated the content of 'Americanism' as the defence of individualism and democracy. This agenda is signalled in a 1950 memorandum from the National Security Council describing Americanism as a doctrine adhered to at home and abroad: 'The fundamental purpose of the United States is ... to assure the integrity and vitality of our free society, which is founded upon the dignity and worth of the individual. The free society attempts to create and maintain an environment in which every individual has the opportunity to realize his creative powers. It derives its strength from its hospitality even to antipathetic ideas' (in Etzold and Gaddis 1978: 386, 387-8). This characterization of American democracy - and there are numerous comparable formulations - is a complement to the external cold war strategy of containing communism 
(and for critical reviews of NSC 68 see Schilling et al. 1962 and Hammond 1969). It emphasizes individualism and democratic rights of citizenship. But this very defence influenced external commentary about the United States.

Scholars have increasingly recognized one of the surprising and unintended consequences of America's global role as a model of liberal democracy in the Cold War years: it exposed domestic practices and policies to external scrutiny, to an extent that intensified the reform of civil rights in the 1960s (Dudziak 2000; Klinkner and Smith 1998; Kryder 2000; Layton 2000; Plummer 1996; Von Eschen 1997). The main object of this scrutiny was the United States' egregious treatment of African Americans and other minorities. (Already in 1919, Woodrow Wilson's articulation of his 14-point programme for a new world order was challenged by Black Americans setting out their 14-point programme for the achievement of democracy at home (Rosenberg 1999).) Writing from jail in Birmingham, Alabama in 1963, Martin Luther King Jr. angrily declared: 'we have waited for more than 340 years for our constitutional and God-given rights. The nations of Asia and Africa are moving with jetlike speed toward gaining political independence, but we still creep at horse-and-buggy pace toward gaining a cup of coffee at a lunch counter.' Both the United Nations' agenda-setting in human rights and the rapid decolonization of the European empires' former colonial peoples created a context for advancing civil rights in the United States.

British and French newspapers provided detailed coverage of African Americans' civil rights struggles in the post-1945 decades. Correspondents both reported new developments in respect to lynching, segregation, presidential initiatives and Supreme Court decisions; and provided detailed historical portraits of the experience of Black Americans and the obstacles they faced. Of the latter sort for instance Le Monde ran a lengthy six-part series by Henri Pierre, 'Les noirs aux Etats-Unis', over a week in June 1950 (the first of which was tellingly entitled 'Problème "Noir" ou problème "Blanc"?'); comparable series appeared in Le Figaro and La Croix in France and the Manchester Guardian and The Economist in Britain. Individual lynchings received detailed coverage overseas, as in due course did both the Brown decision (1954) and 'Little Rock crisis' (1955). 
To some extent French interest in African Americans' conditions was informed by anti-Americanism. Particularly during the period when the Parti Communiste Français (PCF) was a powerful presence in French politics, an eagerness to unearth defects in American politics and society was not uncommon. In 1946 Jean Paul Sartre, the doyen of the French intellectual left, published a critical account of Black Americans in the PCF's Combat. But to explain French interest in the civil rights of Blacks solely by anti-Americanism would produce a partial account for several reasons. Black Americans, such as Josephine Baker and Sidney Bechet, had been important figures in French cultural life during the inter-war decades, and in the post-war years Paris-settled writers such as Richard Wright and James Baldwin maintained this interest.

Indeed, French affection for Americans was strong after 1918 , as the role of the United States in contributing to France's victory was recognized. Black American soldiers served alongside French soldiers at the end of the Great War, a role they did not achieve within the US military force. In Britain during the Second World War American GIs were welcomed, but many British people found African American soldiers far more polite and interesting than the white recruits, and were often disturbed by the beatings whites meted out to their black colleagues. This positive view contributed to subsequent British interest in civil rights in the United States.

Despite the passage of civil rights legislation in the 1960s, aspects of the United States' race politics continue to engage foreign commentary and engagement. The debate about the possible racial bias of prison inmates facing capital punishment has been widely aired in Europe, and the retention of capital punishment itself has been criticized (instanced by French protests about the intention of the Attorney General to seek it in respect of terrorist suspect Zacarias Moussaoui, a French national, post-'September $\left.11^{\prime}\right)$. The use of racial profiling by state and local police forces is another aspect of the United States' domestic practices analysed abroad.

Events, internal and external, inevitably exert pressure on the balance of these individualist and group tendencies. Engagement in foreign conflicts has commonly had integrative effects - they have heightened Americans' sense of 
shared national identity - though in the long term such interventions have also effected profound social and political changes. For instance, the Japanese attack on Pearl Harbor, in 1941, and the terrorist bombing of the World Trade Center and Pentagon, in 2001, had integrative effects: Americans disregarded differences between internal groups to forge common responses. In contrast, the United States' entry into the Great War and the Vietnam War had significant disintegrative consequences: German-Americans suffered during the first event, giving up their identity, while in the latter the fabric of American society was challenged and changed irreversibly. And of course even those events that were outwardly most integrative had significant lines of division: in 1941 Japanese Americans encountered swift retribution for the Hawaiian bombing, with 120,000 interned under emergency legislation.

US foreign policy has often elicited distinct responses from different groups of Americans. Ethnic lobbying on foreign policy is longstanding: for instance, Jewish Americans' interest in the Middle East or Irish Americans' advocacy of Irish nationalism. African Americans have often found themselves at odds with US foreign policy, opposing US support of South African apartheid more vigorously and earlier than many policy-makers. In an earlier period, African Americans were dismayed by the failure of the United States to object to the Italian invasion of Ethiopia in the 1935. But the 2001 terrorist attack is unlikely to garner any such divisions among Americans.

\section{The continuing narrative}

Democratization is a continuing process as the internal boundaries of American nationhood are challenged and redrawn in various ways, for instance by the Japanese American movement to win compensation for wartime incarceration, and by the United States' international roles in defending liberal democracy against alternative ideologies and belief systems - what the political scientist Samuel Huntington calls the 'clash of civilizations' (1996). Domestically some scholars - such as Robert Putnam - argue that 
the multiplicity of groups in US society and the diversity of experience between rural and urban America and between immigrants and non-immigrants harms the level of social capital, therefore damaging the resilience of democracy. Other scholars have emphasized how variations between states about voter registration may discriminate between citizens (for example, the disbarring of former felons in some states). Globally the United States' role as a defender of Western democracy against extremist ideologies has both fanned the resurgence of anti-Americanism and underlined its international presence. We consider these domestic and international roles in turn.

\section{Democracy at home}

The notion of 'one people' expressed in American nationhood has been a constant for over two centuries; but the parameters of who is included, who is excluded and how these relationships are defined is never fixed. Negotiating these inclusions and exclusions creates unexpected issues. For instance, since the late 1960s Native Americans have restructured their relationship to the United States. On Thanksgiving Day in 1970 a group of Native Americans sailed a replica of the Pilgrims' Mayflower ship and threw a dummy of a pilgrim in the water. The event was declared the first National Day of Mourning in commemoration of the victims of the European conquest of the United States. It has become an annual pilgrimage. It signalled a wider set of issues about the relationship between Native Americans and American nationhood. In the last decade and a half the repatriation of American Indian human remains has become integral to the way in which Native Americans configure their relationship to the American nation. Stretching back to the nineteenth-century traditions of ethnology, physical anthropology and phrenology, scientists have collected thousands of skulls and other remains from American Indians, often from battle sites. Many were stored in the Smithsonian Institution, which opened in 1846. Some of these were acquired with appropriate permission, but many were taken fraudulently or by stealing from mass grave-sites. Native 
Americans have increasingly sought the return of these human remains for proper burial in appropriate places in ways that respect tribal cultural beliefs. Especially those remains of American Indians who died on battlefields need the full honours of a traditional burial. The Pan-Indian Repatriation Movement lobbies for federal and state laws to permit repatriation and to proscribe further dissipation of human remains. These demands have had some success with the passage of both the Native American Grave Protection and Repatriation Act in 1990 (requiring all federal institutions to compile inventories of their collections of Indian human remains and artefacts for repatriation where appropriate) and laws in over ten states (Thornton 2001: 159-61). The National Museum of the American Indian, created in 1989, is required also to inventorize its cultural and sacred objects with a view to repatriation.

One of the most influential meditations upon the state of American democracy in the last quarter of the twentieth century is found in the political scientist Robert Putnam's Bowling Alone (2000). Building on his and other scholars' arguments about the need for high levels of trust generated through voluntary civic participation as the basis for a strong civic society, Putnam finds a decline in the social capital necessary for such processes to function. Putnam's book charts a decline in community involvement and social connectedness in the US polity. He argues that a combination of structural changes in American society such as changing family household arrangements, suburbanization, and the diffusion of television as the main medium of entertainment - have coincided with a marked decline in civic engagement by Americans measured in terms of participation in voluntary organizations and membership of social activities. This decline in social capital matters, Putnam maintains, because it has fundamental effects upon social and political interactions. High social capital implies the existence of high interpersonal trust, which permits the resolution of collective action problems through cooperation rather than formal contracts; it also reduced the demand for government in certain areas of life, thereby curbing tax demands. Putnam emphasizes the political costs of the decline in social capital in America, writing that 'nowhere is the need to restore connectedness, trust, and 
civic engagement clearer than in the now often empty public forums of our democracy' (2000: 412). He calls for reform of campaign finance rules, an aspiration met by the Congress in March 2002 when both houses enacted a fundamental revision of the rules governing 'soft money' donations to electoral campaigns.

There has been much criticism of and debate about Putnam's work. Some critics find his social capital agenda unattractive, while others remain sceptical about the causal status of the correlation between the general social trends he sets out and levels of civic engagement. The national and patriotic response to the bombings of 11 September seemed to mark a potential resuscitation of community-based engagement of the sort Putnam advocated. What is not in doubt is either the enormous impact of his concept of 'bowling alone', as a description of reduced civic engagement, among many Americans or the international diffusion of the concept (Putnam 2002).

\section{Democracy abroad}

Despite making little of foreign affairs during his electoral campaign, President George W. Bush has reverted, since 11 September 2001, to the tradition begun with Woodrow Wilson in 1917 of articulating a distinct global role for the United States, one rooted in the beliefs valued in domestic politics. The cornerstone of the Bush administration's approach is a war against global terrorism and the states that support terrorist activity. Bush has specified an 'axis of evil' aligned aggressively against Western democracy. On 20 September 2001 he told Congress that every country fell into one of two camps: 'either you are with us [the US] or you are with the terrorist'.

Citing values closer to those of his Democratic predecessor Bill Clinton than those of many Republicans, President Bush has stressed the diversity of the United States and its openness to all religions and beliefs within the twin context of loyalty to the American nation and the constitutional separation of church and state. Bush declared, 'in a free society, diversity is not disorder. Debate is not strife. And 
dissent is not revolution. A free society trusts its citizens to seek greatness in themselves and their country.' He presents this conception of a 'free society' as a model for international emulation. In his state visit to China in February 2002, President Bush used his live broadcast as an occasion to proselytize to Chinese people the virtues of democracy and American values: 'life in America shows that liberty, paired with law, is not to be feared'. The US is conducting a global war of ideas both to promote democracy and to revise the received views of American institutions. To this end, a new position, under-secretary of state for public diplomacy and public affairs, has been created at the State Department.

The international stance of the Bush administration towards human rights originates with the policy initiated during President Jimmy Carter's incumbency of the White House (1977-80). Carter campaigned on and implemented a foreign policy for the United States sensitive to international human rights and ethics (Foot 2000). Speaking in December 1974, the future Democratic president proclaimed his dream that 'this country set a standard within the community of nations of courage, compassion, integrity, and dedication to basic human rights and freedoms' (quoted in Foot 2000: 43). The United States was also associated during the Carter presidency and subsequently with devising mechanisms to enshrine this priority in the federal government's own institutions. At the Department of State, the Bureau of Human Rights and Humanitarian Affairs was created. The Bureau's staff were responsible for compiling human rights assessment reports on every country receiving US aid, a brief extended later to other countries who were members of the United Nations. Carter appointed Patricia Derian, a veteran of the civil rights movement, to serve as Assistant Secretary in charge of the Bureau. This initiative was continued by the Reagan administration and over twenty years later - by the time of President George W. Bush's presidency - the agency had been renamed the Bureau of Democracy, Human Rights and Labor (still located in the Department of State, website: www.state.gov/www/ global/human_rights/). It issues an annual human rights report that receives wide publicity in the international community and media. Its report on 2001 singled out human 
rights abuses in China, Russia and Saudi Arabia; but the Bureau's remit was set broadly, with the government of the Republic of Ireland, for instance, finding itself criticized for poor standards in prisons.

\section{Conclusion}

External attacks upon the American state heighten Americans' sense of unity and shared nationhood. This effect is pronounced or deflated according to how Americans behave toward their fellow citizens: if there are groups of Americans whose ethnicity or national background render them vulnerable to association with the external enemy, and that connection is drawn, then any fresh unity is dinted. The September 2001 terrorist bombings failed to stir up such internal group divisions (though a number of suspicious deaths may have been motivated by anti-Arab sentiment, and close to a thousand suspects, overwhelmingly immigrants, were arrested). This gave them a unique significance as a mechanism of political integration in the US polity.

Initially, a striking effect of the September 2001 bombings has been to transcend domestic divisions based in race, class, ethnicity or national background. The United States has historically been riven with internal cleavages drawn along lines of race, ethnicity, national background and region. These cleavages have not evaporated, but their political salience declined in the wake of the Islamic bombings. Americans per se were the objects of the Islamic terrorists. And because the United States has advanced politically so much since the civil and voting rights acts enacted in the 1960s in terms of black political participation and achievement, it is an integrated polity and people that experienced this onslaught. The massive sales of the American flag illustrate national unity and the sense of patriotic inclusion.

The September bombings forged Americans' sense of national identity in another way too: they underline the existence and strength of an ideology of anti-Americanism present in certain parts of the world. Anti-Americanism is not new. 
Several threads to this ideology need to be disentangled. First, during the Cold War years communist states and their supporters engaged in immense efforts to cultivate antiAmericanism, especially in West European democracies and in Third World countries. This strand has declined in significance. Second, emerging during the Cold War years, but retaining its influence, is a set of anti-American critiques linking US economic and political power with the maintenance of undemocratic regimes and governments. The writers of such intellectual analyses - for instance, those of orientalism or post-colonialism or dependency theory have not always singled out the United States explicitly, but have often done so implicitly. Third, in the 1990s Americanization has been equated with globalization, and the antiglobal capitalism movement has therefore often explicitly attacked the United States and its policies. Critics of the International Monetary Fund, the World Bank and other international organizations such as the World Trade Organization have often equated these organizations' policies with those of the United States. This tendency has encouraged simplistic explanations of Third World problems that blame the United States. Fourth, American culture is a continuing source of critique by Western intellectuals. Despite the huge success of American mass culture, a dichotomy endures abroad between elite hostility to American values and cultural products and popular embracing of them. In many Arab countries, significantly, the dichotomy is reversed: the educated elites welcome Americanization, for its association with democracy, while the increasingly fundamentalist masses despise American values and culture. Finally, antiAmericanism has been stirred by the ultramontane fanaticism espoused by some Islamic fundamentalists. Both religion (for instance, anti-Christianity) and politics (for example, anti-Israeli proclamations) feature in this coagulation.

The combined effect of these threads constitutive of anti-Americanism has been to render anti-Americanism an ideological world-view, a way of seeing the world and interpreting international events (Christie 2002). The United States' economic power, political democracy, and cultural influence are assimilated into a single entity, the object of hatred and criticism for anti-Americans dispersed throughout the world. In its most sinister form, anti-Americanism 
is paraded out as an explanation for all evils - political, economic or cultural - and anti-American ideology enables its advocates to explain how unrelated phenomena are in fact part of an integrated ideology and world presence. While this anti-Americanism is a continuing challenge to the values of the United States at home and abroad, it has also proved, in the short term, a source of strengthened nationhood. 